\title{
Dominant interfering alleles define a role for c-Myb in T-cell development
}

\author{
Pratipa Badiani, ${ }^{1}$ Paola Corbella, ${ }^{2}$ Dimitris Kioussis, ${ }^{2}$ Jacqueline Marvel, ${ }^{1,3}$ and Kathleen Weston ${ }^{1}$ \\ ${ }^{1}$ Institute of Cancer Research, Chester Beatty Laboratories, London SW3 6JB, UK; ${ }^{2}$ National Institute for Medical Research, \\ The Ridgeway, Mill Hill, London NW7 IAA, UK
}

\begin{abstract}
The transcription activator $c-M y b$ is expressed at high levels in immature thymocytes and during $T$-cell activation and may be a regulator of $\mathrm{T}$-cell differentiation. To investigate the role of $\mathrm{c}$-Myb in T-cell development, we generated transgenic mice in which two dominant interfering Myb alleles, one a competitive inhibitor of DNA binding, and the other, an active repressor comprising the Myb DNA-binding domain linked to the Drosophila Engrailed transcription repressor domain, were expressed from early times onward in $T$ cells. Both alleles partially blocked thymopoiesis and inhibited proliferation of mature T cells. The Myb-En chimera was the more efficient repressor and might serve as an archetype for the manufacture of other dominant interfering transcription factor alleles.
\end{abstract}

[Key Words: c-Myb; dominant interfering alleles; $\mathrm{T}$ cells; proliferation]

Received December 2, 1993; revised version accepted February 3, 1994.

The c-myb proto-oncogene encodes a DNA-binding transcription activator whose expression in vertebrates appears to be almost completely restricted to a limited range of differentiating cell types, most notably the hematopoietic lineage (for review, see Weston 1990). A large body of evidence indicates that $\mathrm{c}-\mathrm{Myb}$ protein is intimately involved in the regulation of cell growth and differentiation during hematopoiesis. $\mathrm{c}-\mathrm{Myb}$ is expressed at early times during hematopoietic differentiation and is down-regulated as cells mature and cease to proliferate (Sheiness and Gardinier 1984; Duprey and Boettiger 1985; Thompson et al. 1986; Liebermann and HoffmanLiebermann 1989). In tissue culture, aberrant overexpression of c-Myb during artificially induced differentiation inhibits maturation of a number of erythroid and myeloid cell lines (Clarke et al. 1988; McMahon et al. 1988; Todokoro et al. 1988; Yanagisawa et al. 1991); conversely, ablation of $\mathrm{c}-\mathrm{Myb}$ expression by the use of $c-m y b$-specific antisense oligonucleotides greatly reduces colony formation by bone marrow and peripheral blood mononuclear cells and the growth of a number of myeloid leukemia cell lines and normal human $\mathrm{T}$ lymphocytes (Gewirtz and Calabretta 1988; Anfossi et al. 1989; Gewirtz et al. 1989). Mice homozygous for a null allele of $c-m y b$ fail to survive past day 15 of fetal life because of an inability to sustain hepatic erythropoiesis (Mucenski et al. 1991); analysis of other developing hematopoietic lineages in the fetuses showed that these were also gravely affected.

During T-cell differentiation, $\mathrm{c}-\mathrm{Myb}$ is expressed at

${ }^{3}$ Present address: Laboratoire de Biologie Moleculaire et Cellulaire, Ecole Normale Superieure de Lyon, 69364 Lyon, Cedex 07, France. high levels in immature thymocytes of the thymic cortex. As in other hematopoietic lineages, the gene is switched off as cells mature, but it becomes active again when resting $\mathrm{T}$ cells in the periphery are stimulated to proliferate by exposure to antigen (Reed et al. 1986; Stern and Smith 1986; Churilla et al. 1989). Expression peaks as the activated cells undergo $G_{1}$ progression, and it has been proposed that c-Myb expression is required for the onset of S phase (Gewirtz et al. 1989). In addition to its potential role in T-cell activation, c-Myb might also be expected to be a regulator of thymocyte development; as in other lineages, inappropriate down-regulation of c-Myb activity could result in inhibition of the proliferative capacity of immature thymocytes and, hence, disruption of T-cell ontogeny. c-Myb may therefore be a crucial player in both differentiation and activation of $T$ cells, and elucidation of its role in these processes would be of great interest.

In vivo studies of the effects of loss of c-Myb expression on T-cell development have been prevented by the embryonic lethal phenotype of the Myb null allele. In an alternative strategy, we have explored the feasibility of using tissue-specific dominant interfering Myb alleles to block the effects of endogenous c-Myb protein. We have approached the problem in two ways. The first interfering allele is a simple competitive inhibitor, a truncated version of $\mathrm{c}-\mathrm{Myb}$ containing only the DNA-binding domain of the protein and lacking the Myb activator domain. The second comprises the Myb DNA-binding domain fused to the repressor domain of the Drosophila Engrailed (En) transcription factor. This alanine-rich region is a strong active repressor of transcription (Jaynes and O'Farrell 1991; Han and Manley 1993), and is fur- 
thermore transplantable; fusion of a 298-amino-acid region containing the domain to the DNA-binding domain of the glucocorticoid receptor creates a chimeric transcriptional repressor that acts through a glucocorticoid response element (Jaynes and O'Farrell 1991). In transient expression assays, both alleles repressed v-Myb-activated transcription efficiently, and the Myb-En chimera could also switch off transcription induced by the SV40 enhancer, when bound to an adjacent site. Using the two alleles, we established lines of transgenic mice in which expression of the constructs was directed in a tissue-specific manner to $\mathrm{T}$ cells by use of the $\mathrm{CD} 2$ locus-controlling region (LCR; Greaves et al. 1989). Expression of either construct resulted in severely impaired T-cell development and also affected the proliferation capacity of activated $T$ cells. The phenotypes of the two alleles were almost identical, indicating that the En portion of the chimeric construct was inert save for its Mybdirected activity. However, the expression level of the Myb-En chimera required for generation of a strong phenotype was $\sim 50-100$-fold lower than that required by the competitive inhibitor construct and considerably less than that of the endogenous c-myb gene. Our data provide direct evidence for the role of $\mathrm{c}-\mathrm{Myb}$ in T-cell ontogeny and suggest a way in which effective interfering transcription factor alleles can be easily generated.

\section{Results \\ Construction and DNA-binding properties of $M y b$ dominant interfering alleles}

The structure of the murine c-Myb protein is outlined in Figure 1A. The protein contains an amino-terminal DNA-binding domain, recognizing the specific consensus binding site PyAACG/TG (Biedenkapp et al. 1988), a transcription activator domain, and at its carboxyl terminus, a region thought to be involved in down-modulation of the protein's activity (Sakura et al. 1989; Ramsay et al. 1991; Dubendorff et al. 1992). To generate a simple competitive inhibitor, the c-Myb protein was amino- and carboxy-terminally truncated to produce a protein comprising the minimal DNA-binding domain, tagged for identification purposes with the 11-aminoacid 9E10 c-myc epitope (Evan et al. 1985). This putative dominant interfering allele was termed MT (MybTag). The second interfering allele was generated by fusing the minimal DNA-binding domain used in the MT allele to amino acids 2-298 of the Drosophila En protein, encompassing the previously defined En repressor domain (Jaynes and O'Farrell 1991). This allele, also 9E10-tagged, was termed MEnT (MybEnTag).

When translated in rabbit reticulocyte lysate, both the 21-kD MT and 55-kD MEnT proteins were stable and were expressed at approximately equivalent levels (Fig. $1 \mathrm{Cl}$. To determine the DNA-binding properties of the two proteins, gel retardation assays with equal amounts of the reticulocyte lysate-translated proteins were performed with a labeled oligonucleotide containing the strong Myb-binding site defined as mimA in the Myb-
A
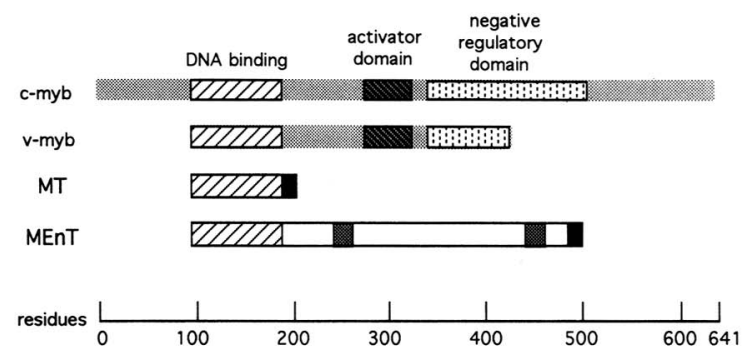

B

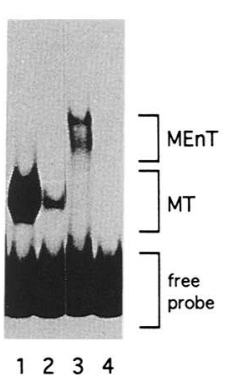

C

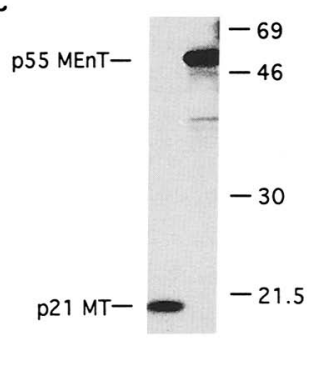

Figure 1. Structure, DNA binding, and stability of the Myb derivatives. $(A)$ Schematic representation of the MT and MEnT alleles relative to c- and v-myb. (Hatched box) Myb DNA-binding domain; (solid box) Myc Tag epitope; (shaded boxes) Krüppel homology regions. $(B)$ Gel retardation assay with labeled Mybbinding site mimA as probe. (Lanes 1,2) MT protein; (lanes 3,4) MEnT protein; (lanes 2,4) 100-fold excess of unlabeled mimA oligonucleotide. $(C)$ SDS-PAGE of $\left[{ }^{35} \mathrm{~S} \mid\right.$ methionine-labeled MT and MEnT proteins made in rabbit reticulocyte lysate. Molecular weight markers (in kilodaltons) are indicated at right.

regulated mim.1 promoter (Ness et al. 1989) as probe. As can be seen in Figure 1B, MT protein bound the mimA probe very efficiently (lane 1), and MEnT, although less efficient than MT, also gave a strong signal (lane 3); in each case, a 100 -fold excess of cold mimA oligonucleotide competed well with labeled probe (lanes 2,4$)$. Both proteins were more active than was an equivalent amount of reticulocyte lysate-translated murine c-Myb (data not shown), perhaps reflecting the loss of inhibitory sequences present in the carboxyl terminus of $\mathrm{c}-\mathrm{Myb}$ (Ramsay et al. 1991).

\section{Repression properties of the Myb dominant interfering alleles}

The abilities of the MT and MEnT alleles to act in a dominant negative fashion were first evaluated in transient transfection assays. Experiments were designed to test first whether the proteins could act as competitive inhibitors, and second, whether they could suppress the activity of a cis-linked enhancer sequence.

In the first series of experiments, an expression vector encoding either MT or MEnT was cotransfected in increasing amounts into HeLa cells together with $5 \mu \mathrm{g}$ of an effector plasmid encoding the chicken $\mathrm{v}$-Myb protein, and a reporter plasmid in which $5 \mathrm{mimA}$ sites were linked to a chloramphenicol acetyl transferase (CAT) 
gene driven by the thymidine kinase $(\mathrm{tk})$ promoter. The $\mathrm{v}-\mathrm{Myb}$ protein (diagramed in Fig. 1A) was chosen as effector rather than c-Myb as it is a stronger activator, and any repression would therefore be more marked; there is no difference in the DNA-binding consensus of the two proteins (Howe and Watson 1991; Weston 1992). A plasmid encoding a herpes simplex virus- 1 immediate early 3 (HSV-1 IE3)-promoter-driven $\beta$-galactosidase gene was included in all transfections both as an internal control for transfection efficiency and as a marker for any nonspecific effects on transcription caused by expression of the repressor proteins; in all experiments performed, we saw no significant differences in the levels of control $\beta$-galactosidase activity, whether or not repressor proteins were present. A representative CAT assay is shown in Figure 2, below the summarized data from several experiments. Activation by $\mathrm{v}-\mathrm{Myb}$ protein results in an $\sim 10$-fold increase in CAT activity relative to that observed when empty expression vector is cotransfected with the mimA-tkCAT reporter. If $5 \mu \mathrm{g}$ of MEnT expression vector is added to the transfection, $\mathrm{v}-\mathrm{Myb}$ activation is reduced almost to background levels; $10 \mu \mathrm{g}$ of MEnT expression vector has an even greater effect. To confirm that the MEnT protein is working solely via binding to the mimA sites, we also cotransfected $15 \mu \mathrm{g}$ of expression vector encoding the En repressor domain; this had no effect on v-Myb-mediated activation (data not shown). When the MT protein is tested in the same assay, the addition of as much as $15 \mu \mathrm{g}$ of MT expression vector only reduces activation by approximately half. These results therefore show that the MEnT and MT proteins will both work as competitive inhibitors and imply that MEnT is more efficient.

We then tested whether the MEnT allele could inhibit the activity of an enhancer when bound adjacent to it. A tkCAT reporter gene linked to the strong SV40 enhancer and carrying $5 \mathrm{mimA}$ sites $5^{\prime}$ to the enhancer was cotransfected with increasing amounts of the two repressors. Five micrograms of MEnT expression vector was sufficient to severely attenuate the activity of the SV40 enhancer, and $10 \mu \mathrm{g}$ had an even more marked effect, reducing CAT activity by an order of magnitude. Cotransfection of the MT repressor had no consistent effect, however. The MEnT protein therefore appears to be working as an active repressor, able to inhibit transcriptional activation from a strong heterologous enhancer. As the relative levels of MT and MEnT proteins in the transfections were not determined, differential
A

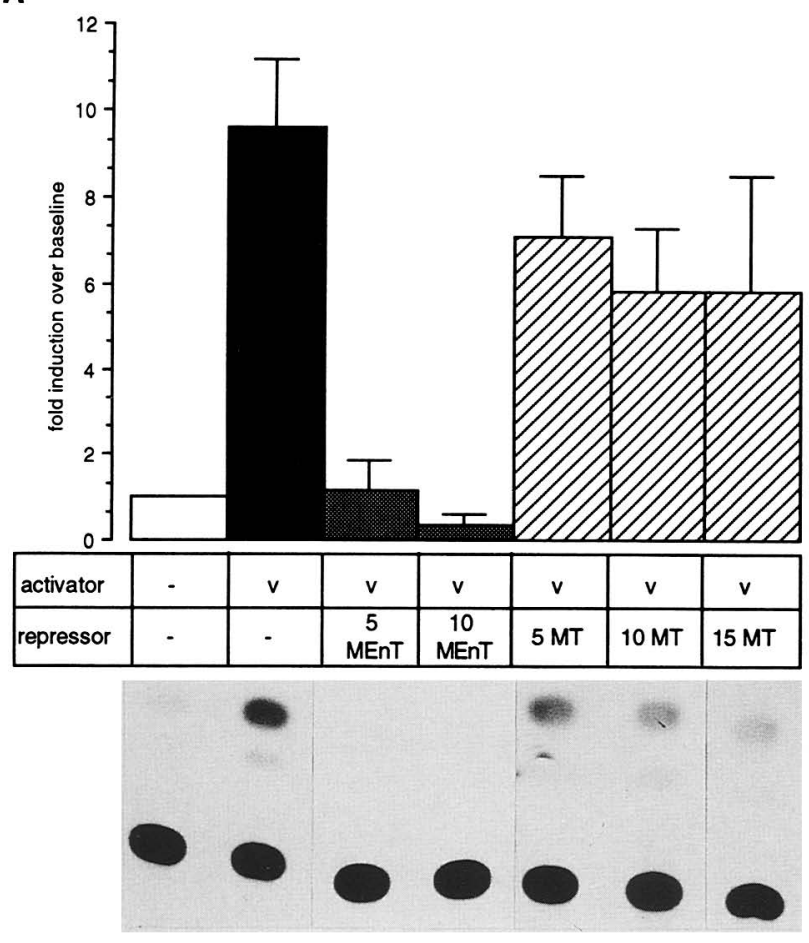

B
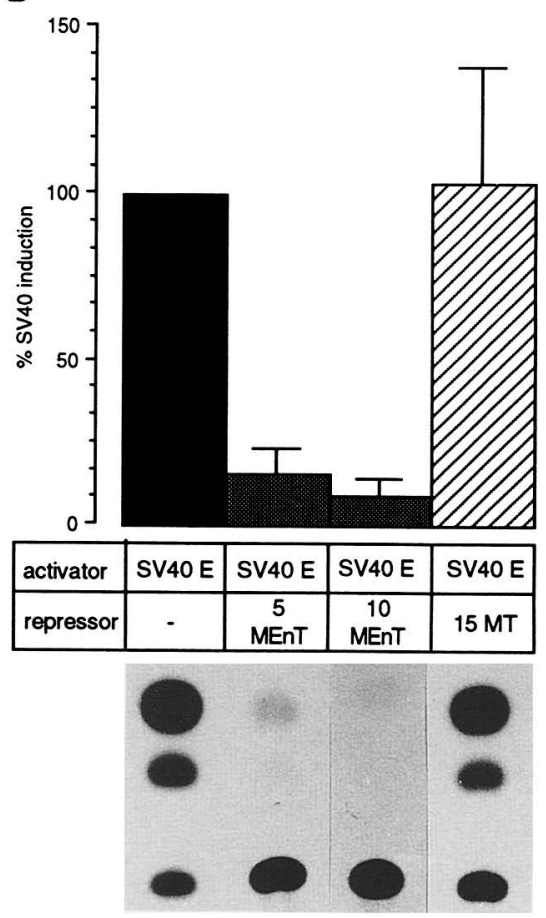

Figure 2. Repression of the activity of reporter promoters by the MT and MEnT proteins. (A) Competitive inhibition of v-Mybdependent activation of reporter plasmid $5 \mathrm{mim} / \mathrm{CAT}$. Amounts of cotransfected repressor plasmid (in micrograms) are as shown. The bar chart shows levels of CAT gene activity expressed as fold induction over baseline. Data represent the mean and standard deviation of four to seven independent experiments and are corrected for $\beta$-galactosidase levels. A representative CAT assay appears below. (B) Active repression of the SV40 enhancer. The bar chart shows levels of CAT gene activity as a percentage of the activity of the $5 \mathrm{mim} / \mathrm{SV} / \mathrm{CAT}$ reporter gene transfected in the absence of repressor plasmids. Amounts of cotransfected repressor plasmid (in micrograms) are as shown. Data represent the mean and standard deviation of four to seven independent experiments. A representative CAT assay is shown below. In this example, some levels of CAT activity are outside the linear range of the assay; in all instances where this occurred, extracts were diluted and reasssayed to derive the data presented in the bar chart. 
protein stability cannot be ruled out as an explanation for these data. However, in transgenic mice (see below), a far greater amount of MT protein is required to mimic the phenotype induced by low levels of MEnT expression, confirming that MEnT is by far the stronger repressor.

\section{Expression of the Myb dominant interfering alleles in transgenic mice}

Having generated dominant interfering alleles of Myb that were effective in tissue culture, we decided to examine their effects in vivo. The MT and MEnT dominant interfering alleles were used to establish lines of transgenic mice designed to express the alleles in a tissuespecific manner in developing and mature $\mathrm{T}$ cells.

Constructs were made in which the MT and MEnT genes were expressed from the human $\beta$-globin promoter and linked to a fragment of the human CD2 locus controlling region (LCR), which has been shown previously to direct position-independent, copy-number-dependent expression of linked genes throughout T-cell ontogeny (Greaves et al. 1989). A total of seven and five lines, respectively, were obtained from microinjection of the MT and MEnT constructs, containing between 2 and 26 genomic copies of the transgenes. Figure $3 \mathrm{~A}$ shows a Northern blot of total thymic RNA probed with a labeled fragment of the murine c-myb gene encoding the $\mathrm{Myb}$ DNA-binding domain; this probe hybridizes to both endogenous c-my $b$ and transgenic mRNA. Four high-copynumber lines, MT5 and MT6 (lanes 1,2), derived from the MT construct, and MEnT2 and MEnT5 (lanes 3,4),

A
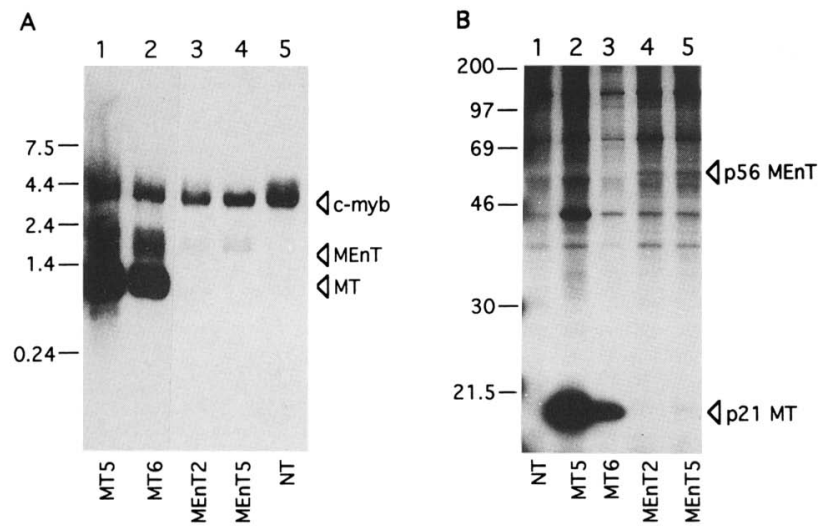

Figure 3. Expression of the MT and MEnT alleles in transgenic mice. (A) Northern blot of total thymic RNA probed with a labeled fragment of the c-myb DNA-binding domain. Sizes (in kilobases) of RNA markers are at left. In each track, $10 \mu \mathrm{g}$ (lanes $1,2)$ or $20 \mu \mathrm{g}$ (lanes 3-5) of RNA was loaded. (B) SDS-PAGE of $\left[{ }^{35} S\right]$ methionine-labeled thymic protein extracts immunoprecipitated with the myc-Tag-specific monoclonal antibody 9E10 covalently coupled to protein A-sepharose beads. Molecular weight markers (in kilodaltons) appear at left. $\left[{ }^{35} \mathrm{~S}\right]$ Methioninelabeled MT and MEnT proteins made in reticulocyte lysates were run on the same gel and comigrated with the MT and MEnT bands indicated by open arrowheads. derived from the MEnT construct, are shown, together with a nontransgenic control (lane 5). The MT5 and MT6 lines express levels of the $0.7-\mathrm{kb}$ MT-specific RNA commensurate with the copy number of the MT transgene $(\sim 26$ and 18 , respectively) and significantly higher than the level of the endogenous 3.8-kb c-myb mRNA. Surprisingly, the two MEnT lines, despite their copy numbers of $\sim 18$ and 12, express only low levels of the $1.67-\mathrm{kb}$ MEnT-specific message relative to the endogenous c-myb mRNA (see Discussion). No expression of the MT and MEnT RNA was detected in tissues other than the thymus, spleen, and lymph nodes of transgenic animals (data not shown).

The marked difference in the expression levels of the MT and MEnT mRNAs is paralleled at the protein level. Figure 3B shows an immunoprecipitation from protein extracts made from thymocytes labeled in vitro with $\left.{ }^{[35} \mathrm{S}\right]$ methionine. By use of an antibody directed against the carboxy-terminal epitope tag of the transgenic proteins, the 21.5-kD MT protein (MT5 and MT6; lanes 2,3), and the 55-kD MEnT protein (MEnT2 and MEnT5; lanes 4,5 ) were specifically precipitated compared with a nontransgenic control (lane 1), but the level of MEnT protein was again very low compared with MT protein. Western blotting of thymic extracts from heterozygous transgenic and nontransgenic mice indicates that the level of endogenous c-Myb is unchanged (R. Marais and K. Weston, unpubl.). However, because of the constraints of available antibodies, it is not possible to make a direct comparison of the MT and MEnT protein levels relative to endogenous $\mathrm{c}-\mathrm{Myb}$.

\section{Effects of the Myb dominant interfering alleles on T-cell development}

The thymuses and spleens of 3- to 6-week-old mice from the 12 transgenic lines established were examined for evidence of any obvious abnormality. In the MT5, MEnT2, and MEnT5 lines, mice heterozygous for the transgene had obviously small thymuses, although their spleens were of normal size. Homozygous mice from these lines had little or no thymus, and spleens reduced to between half and a quarter of normal size. Histological examination of affected thymuses showed that they lacked discernible medullae and had structurally abnormal cortices (data not shown). In the MT6 line, small thymuses were only observed in animals homozygous for the MT transgene. The remaining lines appeared superficially unaffected.

A more detailed analysis of the fate of developing thymocytes in the four overtly affected lines was undertaken by flow cytometry, using a combination of cellsurface markers that together define specific stages in T-cell ontogeny (for review, see Shortman 1992). Broadly speaking, thymocytes can be divided into four main populations on the basis of their expression of the CD4 and CD8 glycoproteins. The majority of the most immature committed thymocytes are negative for both the T-cell receptor (TCR) and its associated components the CD3 complex and the CD4 and CD8 coreceptors. Such cells 
form part of the subset termed double negative (DN) for CD4 and CD8. At late times in the DN stage, cells undergo a burst of proliferation, and the majority start to express low levels of either CD8 or CD4 on their surfaces, prior to becoming double-positive (DP) for these markers. The CD3 complex is also first expressed at low levels during the transition from DN to DP, and thereafter, at high levels. A 50-fold expansion in thymocyte numbers occurs shortly after the DN to DP transition, such that DP cells in the thymus constitute between $70 \%$ and $80 \%$ of the total thymocyte population, and it is at this stage that the $\alpha \beta T C R$ is expressed and the processes of positive and negative selection occur. Finally, those cells that have survived selection mature to become either single positive (SP) for $\mathrm{CD} 4\left(\mathrm{CD} 4^{+} 8^{-}\right)$or $\mathrm{CD} 8\left(\mathrm{CD}^{-}{ }^{-} 8^{+}\right)$, and are ready to exit the thymus.

Figure $4 \mathrm{~A}$ shows the staining profiles for CD4 and CD8 of thymocytes taken from 5- to 6-week-old mice from the MT5 and MEnT2 lines, together with a nontransgenic control. Heterozygotes from either the MT5 or MEnT2 line show a decrease in the ratio of $\mathrm{CD} 4^{+} 8^{-}$ to $\mathrm{CD} 4-8^{+}$cells compared with the nontransgenic control, but the percentage of DP cells is unaffected. However, homozygotes from both lines have a drastically altered profile; the percentage of immature DN cells has increased, and DP cells now only comprise $\sim 35 \%$ of the population. In confirmation of this relative increase in the DN population, the percentage of $\mathrm{CD}^{-}$and $\mathrm{CD} 3^{\text {lo }}$ cells is also increased in both the MT5 and MEnT2 lines, most notably in homozygous transgenics (data not shown). Lymphocytes purified from spleens were also stained for the CD4 and CD8 markers to determine the effect of transgene expression on mature peripheral $T$ cells. As shown (for homozygous mice only) in Figure 4B, there is a diminution in the percentages of single positive cells relative to the nontransgenic control in both the MT5 and MEnT2 lines, and again, the ratio of $\mathrm{CD} 4^{+} 8^{-}$to $\mathrm{CD}^{-} 8^{+}$cells decreases in the transgenics.

Figure 5 shows the flow cytometric data for heterozygous and homozygous animals from the MT5 and MEnT2 lines plotted in terms of absolute cell number. The histograms, for thymus (Fig. 5A) and spleen (Fig. 5B) show each indicated population as a percentage of the nontransgenic population; actual cell numbers are shown beneath the graphs. For both the MT5 and MEnT2 mice, the data are very similar, although MEnT2 animals appear more severely affected; analysis of the MT6 and MEnT5 lines also gave similar results (data not shown). In the thymus (Fig. 5A), the total number of $T$ cells is reduced by 2 - to 4 -fold in heterozygous animals and by $\sim 20$-fold in homozygotes. This reduction in numbers is roughly paralleled in the $\mathrm{CD} 4^{+} 8^{-}$and $\mathrm{CD} 4^{+} 8^{+}$

\section{A THYMUS}
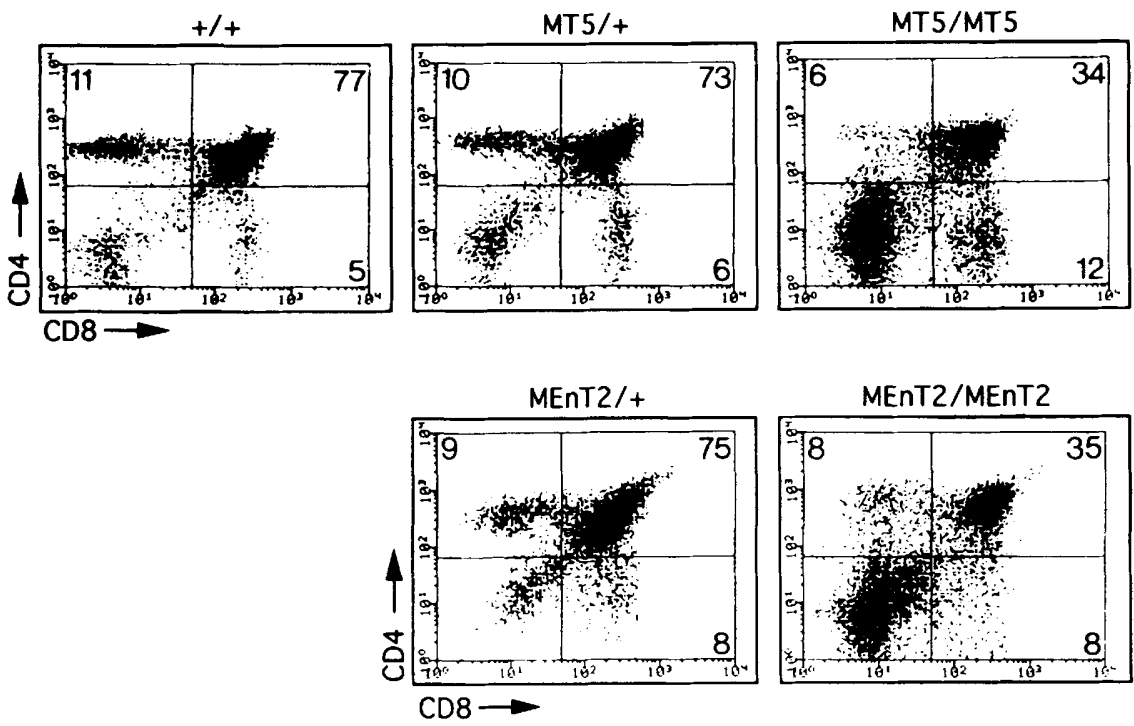

\section{B SPLEEN}

Figure 4. Two-color flow cytometric analysis of CD4 and CD8 surface expression on thymocytes $(A)$ and splenocytes $(B)$ from 6 week old transgenic mice vs. an age-matched nontransgenic control. Equal numbers of lymphocytes were stained in all cases. Percentages of SP and DP cells are as indicated.
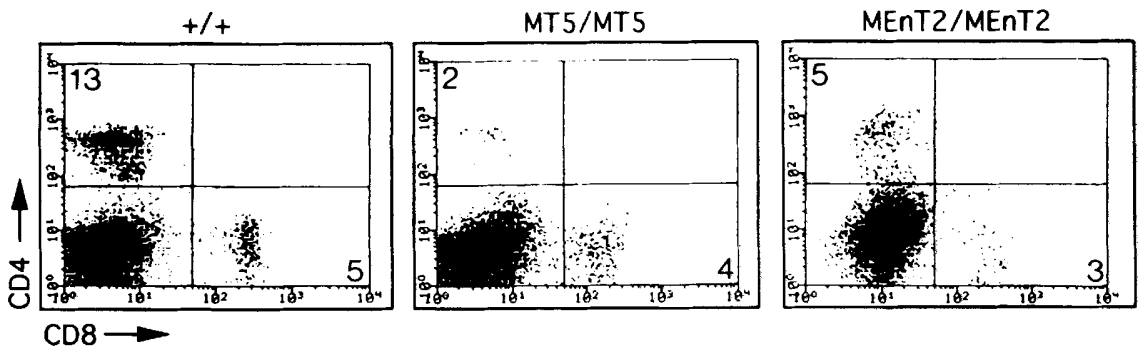


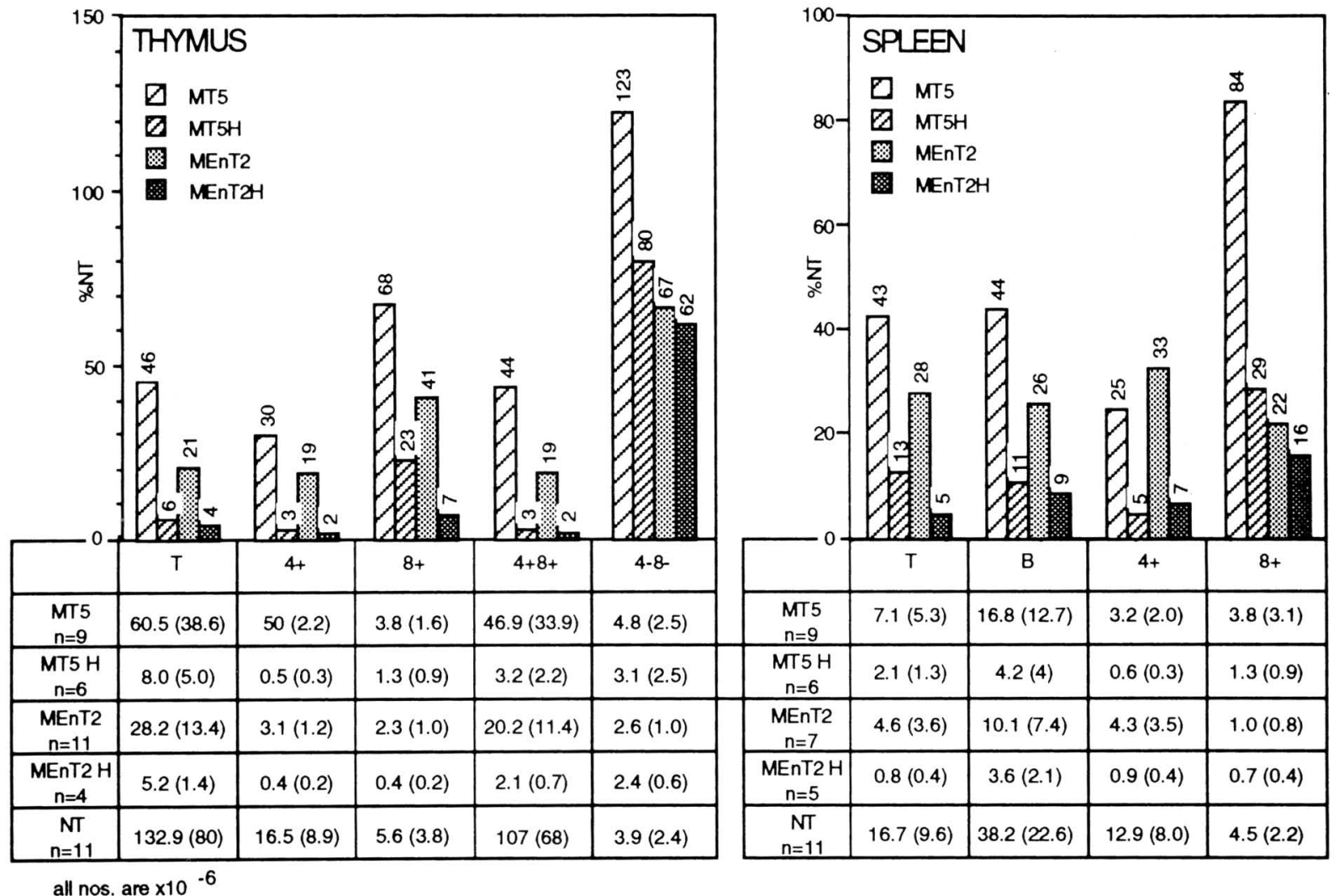

Figure 5. Disruption of T-cell ontogeny in MT and MEnT transgenic mice. The histograms show the numbers of cells present in each analyzed population as a percentage of nontransgenic numbers; actual percentages appear at the top of each bar. The real cell numbers $\left(\times 10^{-6}\right)$ from which these percentages were derived are shown below and represent the mean and standard deviations (in brackets) of cell counts from the indicated number of animals. Total numbers of thymocytes and splenocytes were estimated by staining with antibodies directed against CD45, Thy1.2, and immunoglobulin.

(DP) subsets. The $\mathrm{CD} 4^{-} 8^{+}$cells are less affected, especially in the MT5 line where there is only a fourfold drop even in homozygous animals, explaining the decrease in the ratio of $\mathrm{CD}^{+} 8^{-}$to $\mathrm{CD}^{-} 8^{+}$cells observed in Figure 4. In contrast, the most immature $\mathrm{CD} 4^{-} 8^{-}$DN population is hardly affected in the MT5 line and only drops to $62 \%$ of the nontransgenic DN population in MEnT2 homozygotes, the most severely affected mice. Expression of the Myb dominant interfering transgenes therefore appears partially to block T-cell differentiation at some point during or immediately after the $\mathrm{DN}$ to $\mathrm{DP}$ transition; increasing expression of the transgene by doubling the copy number in homozygous animals increases the severity of the phenotype.

Similar analysis of cells in the spleens of 6- to 12 week-old transgenic animals also showed that there was a parallel reduction in both $\mathrm{T}$ - and $\mathrm{B}$-cell numbers relative to nontransgenic controls (Fig. 5B). Again, this effect was more pronounced in homozygotes, which have increased expression of the transgene. Data obtained from Northern analysis of RNA made from purified splenic B cells indicated that some transgene expression was detectable (P. Badiani and K. Weston, unpubl.), and so the effect on B cells may be cell autonomous. In the T-cell subsets, as in the thymus, $\mathrm{CD}^{+} 8^{-}$cells were depleted more severely than $\mathrm{CD} 4-8^{+}$cells, especially in the MT5 line. It is unclear why the SP $\mathrm{CD} 4^{-} 8^{+}$population should be less affected than the SP CD4 ${ }^{+} 8^{-}$cells, but presumably, as the effect was observed in both thymus and spleen, it involves the mature SP $\mathrm{CD} 4{ }^{-} 8^{+}$population, rather than the immature $\mathrm{CD} 4{ }^{-} 8^{+} \mathrm{DP}$ precursors. Intriguingly, a binding site for $\mathrm{c}-\mathrm{Myb}$ has been described in the CD4 promoter (Siu et al. 1992); we are investigating the possibility that the interfering alleles can inhibit CD4 expression and could perhaps bias DP thymocytes toward selection for the $\mathrm{CD}^{-} 8^{+}$phenotype.

\section{Proliferation of mature T cells in MT and MEnT transgenics}

We next tested the effects of the interfering alleles on the proliferation of mature $T$ cells. Splenic lymphocytes taken from 6-month-old MT5, MEnT2, and nontransgenic animals were assayed for their ability to proliferate in response to the lectin phytohemagglutinin (PHA) or the anti-CD3e monoclonal antibody $2 \mathrm{Cl1}$. Results are shown in Figure 6. For $\mathrm{T}$ cells prepared from heterozygous animals from both lines, proliferation, as measured 


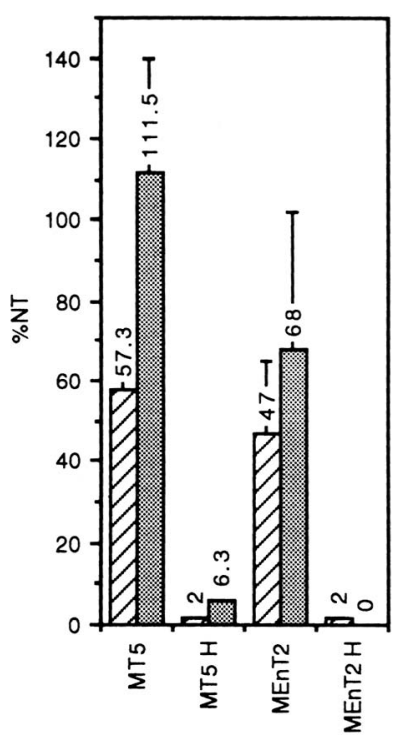

Figure 6. Transgenic $T$ cells fail to proliferate correctly in response to mitogen. The histogram shows the percent incorporation of $\left[{ }^{3} \mathrm{H}\right]$ thymidine (measured as $\Delta \mathrm{cpm}$ ) into transgenic thymocytes relative to age-matched nontransgenic controls. Thymocytes were treated with either $0.3 \mu \mathrm{g} / \mathrm{ml}$ of $2 \mathrm{Cll}$ (anti-CD3e) antibody (hatched bars) or $0.1 \mu \mathrm{g} / \mathrm{ml}$ PHA (stippled bars). Data were derived from 10 heterozygous and 5 homozygous animals from each line.

by $\left[{ }^{3} \mathrm{H}\right]$ thymidine incorporation, was reduced to approximately half normal in response to $2 \mathrm{C} 11$; PHA-induced proliferation was not affected as much, appearing essentially normal in the MT5 line and reduced to an average of $68 \%$ in the MEnT2 line. The reduction in 2C11-induced proliferation could not be explained by the presence of fewer $T$ cells; samples contained equal numbers of lymphocytes, and in heterozygotes, the $\mathrm{B} / \mathrm{T}$ ratio is close to that observed in nontransgenic animals, so that there is a similar percentage of $\mathrm{T}$ cells in each sample $137 \pm 7.3$ for nontransgenics, $38 \pm 6.5$ for MT5, and $29 \pm 3.4$ for MEnT2 mice). The T cells of homozygous MT5 and MEnT2 mice were almost completely unresponsive to either $2 \mathrm{Cl1}$ or PHA, although preparations contained an average of $28 \%$ (MT5) and $15 \%$ (MEnT2) T cells. The Myb dominant interfering alleles therefore appear to have an inhibitory effect on T-cell proliferation. In addition, the inability of homozygous $T$ cells to proliferate properly might partially explain the failure of homozygous MT5 and MEnT2 mice to thrive; animals kept in a conventional facility were frequently runted, and most died prior to 6 months of age from disseminated infections reminiscent of those seen in immunocompromised mouse strains.

\section{Discussion}

The c-Myb transcription factor has been implicated in the control of differentiation in a number of hematopoietic cell lines. Because c-Myb is expressed at its highest levels in immature cortical thymocytes, it has been postulated that it is involved in T-cell ontogeny. However, direct proof of this has been lacking, because mice homozygous for a c-myb null allele die before significant differentiation in the thymus has taken place. To investigate the role of $\mathrm{c}-\mathrm{Myb}$, we therefore decided to express interfering alleles of the protein in murine $T$ cells. Here, we have described the generation of transgenic mouse lines in which two dominant interfering Myb alleles have been specifically targeted to the T-cell lineage. Both alleles cause a partial block in thymocyte differentiation early in ontogeny and, additionally, affect the ability of peripheral $\mathrm{T}$ cells to proliferate in response to mitogen.

\section{Dominant interfering $M y b$ alleles}

Previous attempts to make interfering alleles of transcription activators have focused on inhibiting the activity of wild-type protein by dimerization with an inert mutant (e.g., see Lloyd et al. 1991). We approached the problem in a different way, by fusing the strong repressor domain of the En protein to the minimal DNA-binding domain of c-Myb. This mutant allele, MEnT, was tested in parallel with a second construct, MT, which contained only the Myb DNA-binding domain. In transient expression assays, both MT and MEnT functioned as competitive inhibitors of transcription. However, MEnT also worked as an active repressor; when bound to Myb sites abutting the SV40 enhancer, it was capable of reducing SV40-driven transcription from a linked promoter by an order of magnitude. These data are in good agreement with current theories concerning the mode of action of the En repressor domain (Han and Manley 1993). As En is capable of repressing many different transcription activators and, hence, a complex enhancer such as that of SV40, it is unlikely to be able to quench activation by recognizing a hypothetical conserved binding site on so many diverse proteins. Rather, it has been proposed to interact directly with the basic transcription machinery, such that basal transcription can still occur, but transcription activator binding sites are masked or released from the basal complex.

From the results of the transient expression assays, we reasoned that the MEnT allele should act as a strong dominant interfering mutant, surpassing the activity of the MT allele because of its properties of active repression. Following introduction of the two alleles, linked to the CD2 LCR, into the germ line of transgenic mice, we derived two high copy number lines for both MT and MEnT. Commensurate with copy number, high expression levels of MT protein were detected, as reported previously for constructs linked to the CD2 LCR, but we were only able to demonstrate low levels of expression from the MEnT allele. The reason for this failure of the CD2 LCR to exert its normal effect is not known. A slightly $3^{\prime}$-truncated version of the LCR $(5.1 \mathrm{~kb}$ rather than $5.5 \mathrm{~kb}$ ) was used to make the MEnT transgene, as at the time of construction, the $3^{\prime}$ region of the LCR was not thought to be important for its activity. However, it is possible that the LCR was attenuated, as recent dele- 
tion analysis indicates that progressive removal of $3^{\prime}$ LCR sequences does reduce levels of expression from linked genes (D. Kioussis, unpubl.). Alternatively, autoregulation of the MEnT transgene may be occurring; the CD2 LCR, whose sequence has not been completely determined, may contain a Myb consensus binding site at which the strong active repressor MEnT, but not the passive MT repressor, might act to down-regulate its own transcription. It is also formally possible that MEnT protein may be toxic to cells when it is overexpressed, perhaps because at high levels it might nonspecifically sequester essential components of the transcription machinery (squelching; Gill and Ptashne 1988). If this were true, only those cells able to down-regulate its expression could survive, but the mechanism by which this cell-mediated down-regulation might occur is not apparent. The LCR, or other cis-acting sequences, would have to be mutated in almost all integrated copies (12 and 18, respectively in the two MEnT lines analyzed for expression of the transgene to be reduced to such low levels.

Analysis of the cells populating the thymuses and spleens of transgenic animals showed that the two MT lines with high levels of expression, and the two MEnT lines whose expression levels were 50-100 times lower, had virtually identical phenotypes, in which thymopoiesis was inhibited (see below). Because of the marked difference between the expression levels of the MT and MEnT alleles, and also their different structures and apparent modes of action, we think it is unlikely that the phenotype observed is attributable to some nonspecific toxicity resulting in cell death. A common mechanism whereby a small amount of MEnT and a large amount of the inert Myb DNA-binding domain MT might interfere with cells nonspecifically is hard to envisage; additionally, this toxicity would be confined only to immature thymocytes, as mature $T$ cells are clearly capable of surviving when MT and MEnT are expressed (see below). Instead, we suggest that the observed phenotypes agree well with the transient expression results, demonstrating that in vivo as well as in a model system, MEnT appears to be a far stronger repressor than MT, and that both proteins are acting only via their cognate binding sites. Comparison of MEnT and endogenous $c-m y b$ mRNA levels on Northern blots of total thymic RNA also showed that c-myb mRNA was in excess over MEnT mRNA. It is therefore likely that MEnT can work well even when present at lower levels than endogenous wild-type protein. However, strict interpretation of this result is not possible because of heterogeneous $c-m y b$ expression in the different thymic subpopulations (Sheiness and Gardinier 1984).

The dominant interfering alleles described here are designed to inhibit c-Myb function by competing with the endogenous protein for its target binding site. However, the alleles could also be binding to sites recognized by other Myb-like proteins. Two homologs of the c-myb gene, A-myb and B-myb, have been described (Nomura et al. 1988), both of which can bind to Myb recognition sites on DNA. A-Myb contains a potential acidic activator domain but is not well characterized. B-Myb has been proposed by some workers to be an activator (Nakagoshi et al. 1992/ but appears to act as a competitive inhibitor of c-Myb in the majority of cell lines tested (Foos et al. 1992; Watson et al. 1993). Although the expression of neither gene has been examined during $\mathrm{T}$-cell differentiation, A-myb mRNA has been detected in resting mature $T$ cells and is down-regulated when cells are activated, whereast $\mathrm{B}-m y b$ mRNA is missing in resting $\mathrm{T}$ cells and is induced at late times during activation (Golay et al. 1991). It is possible that some of the effects that we detect with the interfering alleles are attributable to binding at A- and B-Myb sites, and also at potential Myb sites that may be normally occupied by other proteins.

\section{The role of $c-M y b$ in thymocyte development}

Expression of both the MT and MEnT interfering alleles in transgenic mice severely disrupts T-cell development. Thymuses were small and malformed and contained up to 20 times fewer thymocytes than normal. Flow cytometric analysis confirmed that thymocyte maturation had been affected; although the most immature DN population was still present at between $60 \%$ and $80 \%$ of its normal size, a partial block to differentiation had occurred during or after this point, as the DP and SP populations were greatly attenuated. Animals homozygous for the interfering alleles were far more severely affected than were heterozygotes. The drastic increase in the severity of the phenotype between heterozygotes and homozygotes is in contrast to the more modest effects on transcriptional activity observed in the preliminary transient transfection experiments when the concentration of the interfering alleles was doubled. However, given the large burst size during the DN/DP transition /see below), such a magnification is to be expected; if Myb protein is involved in proliferation, doubling the amount of Myb repression in each cell cycle would rapidly lead to a large difference in cell numbers in successive rounds of division.

The blockade of thymocyte development induced by the Myb dominant interfering constructs might not be observed until the DN to DP stage for two different reasons: (1) the CD2 LCR might not be active until this point, and therefore the transgene is not switched on; or (2) the Myb protein is not required for T-cell development prior to this stage. It is currently unclear which of these hypotheses is correct. Transgenic RNA can be detected in purified DN cells (P. Badiani and $\mathrm{K}$. Weston, unpubl.), showing that at least some DN cells are expressing the transgene. However, analysis of the surface expression of the $\mathrm{CD} 2$ glycoprotein during thymocyte differentiation in mice has shown that normally, only $\sim 20 \%$ of DN thymocytes stain for CD2 in adult animals (Rodewald et al. 1993). An analogous situation has also been described for humans (Haynes et al. 1989), and so it seems reasonable to propose that expression of the transgenic constructs is at least attenuated during some of the DN stage. In transgenic MT5 and MEnT2 thymuses, a larger percentage of immature $\mathrm{DN} \mathrm{CD} 2^{-}$cells is present than normal (data not shown); it is possible that up to 
this point in development, the transgenic constructs may not be well expressed and that upon full expression, a partial block to proliferation occurs.

The DN to DP transition affected in the dominant interfering transgenics is a crucial control point during T-cell ontogeny. For example, targeted knockouts of many of the genes involved in the correct assembly and expression of the TCR $\beta$ chain, which appears necessary for thymocyte maturation and expansion during the DN to DP transition (for review, see Palmer et al. 1993), result in a partial or complete block to development at this stage. However, the DN to DP transition is also the time at which the thymocyte population is undergoing extremely rapid expansion prior to positive and negative selection at the end of the DP stage (for review, see Shortman 1992); any disruption of the proliferation of such an active population, whether in a T-cell-specific or nonspecific fashion, would be expected drastically to reduce the numbers of all subsequent progeny. We propose a model in which the dominant interfering alleles of Myb function at early times in T-cell ontogeny by inhibiting proliferation, using regulatory pathways common to most, if not all, immature hematopoietic cells. The proliferation block caused by the interfering alleles is therefore most apparent at the DN to DP transition because of the rapid population expansion at this time. After this point, during selection and maturation of DP to SP cells and the subsequent export of SP cells into the periphery, very little cell division occurs (Egerton et al. 1990), and so cells progressing past the Myb-induced proliferation block might be expected to develop relatively normally.

Although formal proof of a Myb-regulated direct block to proliferation during thymocyte development requires a more detailed analysis than that presented here, our results confirm and extend existing data regarding the importance of $c-m y b$ in growth control. In most hematopoietic cell types examined so far, including mature $\mathrm{T}$ cells, loss of c-myb expression specifically causes growth arrest (e.g., see Gewirtz and Calabretta 1988; Gewirtz et al. 1989). In the c-myb null mice, examination of the development of fetal hematopoietic lineages showed that progenitor cells were still present, but in greatly reduced numbers. As these cells were still capable of differentiation, it was suggested that c-Myb protein might normally regulate the switch between growth and differentiation by maintaining progenitors in a proliferative state (Mucenski et al. 1991). Loss of c-Myb expression would then result in an inability to proliferate, and cells would enter the differentiation pathway instead. This proposition agrees well with our observations.

\section{Proliferation of transgenic T lymphocytes}

Activation of $T$ cells via antigenic stimulation of the TCR results in the transition of cells from $G_{0}$ into $G_{1}$, and the production of interleukin-2 (IL-2) and its receptor (Crabtree 1989). Interaction of IL-2 with its receptor is required for subsequent progression through the cell cy- cle and is the commitment event that triggers T-cell proliferation (Cantrell and Smith 1984). Studies on the expression of $c-m y b$ during this process have shown a biphasic induction pattern (Reed et al. 1986; Golay et al. 1991). c-myb mRNA is upregulated $3-6 \mathrm{hr}$ after TCR stimulation, and then strongly expressed during $G_{1}$ following the engagement of the IL2-R by IL-2. IL-2-induced progression from $G_{1}$ into $S$ phase has been shown to be inhibited in the presence of c-myb-specific antisense oligonucleotides (Churilla et al. 1989; Gewirtz et al. 1989). As expected from these data, the dominant interfering Myb alleles had an inhibitory effect on T-cell proliferation in response to mitogen. In homozygous animals, there was an almost total block to proliferation. However, in heterozygous mice, the magnitude of the effect varied, depending on the mitogen used. Proliferation induced by direct cross-linking of the TCR by use of an anti-CD $3 \epsilon$ antibody was affected more severely than that induced upon indirect cross-linking via the lectin PHA. Presumably, the multiple pathways stimulated by PHA provide a stronger proliferative signal to the cells than does signaling solely through the TCR, and this is sufficient to override some of the effects of lower concentrations of the Myb dominant interfering alleles. Direct blockade of the interaction of IL2 with its receptor does not seem to be occurring, as addition of exogenous IL-2 to the assays had no effect on proliferation, and IL-2R was still detectable on the surface of mitogen-treated cells (data not shown). The mechanism by which activation is blocked is currently being further investigated by use of the dominant interfering alleles.

\section{B-cell development in $M y b$ dominant interfering mice}

On examination of the peripheral lymphocytes of transgenic animals, we discovered that in addition to a marked decrease in the number of $T$ cells populating transgenic spleens, numbers of mature $B$ cells were also reduced. This effect is probably cell-autonomous, as we detected expression of the transgenes in purified splenic $B$ cells, and the human CD2 LCR has been shown to function in the B cells of other transgenic lines generated using the $\beta G C D 2$ expression cassette (D. Kioussis, unpubl.). As for all hematopoietic tissues examined, expression of c-Myb has been reported in immature B cells, and it is induced upon in vitro activation of $B$ lymphocytes (Golay et al. 1991). The Myb dominant interfering mice should therefore prove to be useful tools for investigation of the role of c-Myb in B-cell ontogeny.

\section{Conclusions}

By fusion of the DNA-binding domain of Myb to the transplantable repressor domain of En, we have created an interfering allele that appears at least as effective as a far greater amount of simple competitive inhibitor. This method of generating interfering alleles is clearly applicable to other transcription factors. Repressor alleles, unlike null mutations or antisense oligonucleotides, can be easily introduced in a controlled fashion into many ex- 
perimental systems and are therefore potentially extremely versatile. We have shown here that Myb interfering alleles have profound effects on T-cell differentiation when introduced into the murine T-cell lineage and additionally inhibit the proliferation of $B$ cells. We plan to examine more closely the mechanisms by which Myb regulates cell growth by further exploitation of the system we have developed.

\section{Materials and methods}

\section{Plasmid construction}

Plasmid DNA manipulations and preparation were by standard methods. All constructs were checked by restriction mapping, and in-frame fusions, deletions, and products of the PCR were verified by double-stranded sequencing by standard techniques.

For MT construction, a fragment comprising nucleotides 250-636 of murine c-myb (Gonda et al. 1985) was generated by PCR from plasmid pT7ßc-myb (Howe et al. 1990), such that the 5 ' end of the fragment was fused to a BamHI site preceding the $6 \mathrm{gag}$ codons of AMV v-myb (GGATCCATGGAAGCCGT. CATTAAG), and the $3^{\prime}$ end was fused in-frame to a sequence encoding the c-myc 9E10 epitope (underlined) preceded by a HindIII site and followed by a BamHI site (AAGCTTGAG. CAGAAGCTGATCTCCGAGGAGGACCTGAACTAGGGATCC). This fragment was cloned into BamHI-digested pUC12, lacking the EcoRI and SalI sites in the polylinker, to give pUCMT. For MEnT construction, a fragment encoding amino acids 2-298 of the Drosophila engrailed (en) gene (Poole et al. 1985) was generated by PCR from a partial en gene clone (kind gift of N. Gay, University of Cambridge, UK), such that the en DNA carried an NsiI site at either end. Following Nsil digestion, the fragment was inserted into the PstI site at nucleotide 632 of c-myb in pUCMT, to generate pUCMEnT, in which the en fragment was fused in-frame between the c-myb and 9E10 fragments. Sequences at the fusion points are TACCT/GCATGCCCTG ... . CTGGGATCTAT/GCAGAAGCTT.

For in vitro transcription and translation, the MT and MEnT sequences were inserted into pT7 $\beta$ (Pollock and Treisman 1990) by NcoI-BamHI digestion to give pT7 $\beta M T$ and pT7 $\beta M E n T$. For transient transfections, plasmids pSCDMS/MT and pSCDMS/ $\mathrm{MEnT}$ were generated by insertion of BamHI-digested, end-repaired MT and MEnT fragments into the EcoRV site of pSCDMS (Whiteside 1992). Plasmid pMTV, a v-myb expression vector, is described in Weston and Bishop (1989). The reporter plasmid $5 \mathrm{mim} / \mathrm{CAT}$ contains 5 head-to-tail copies of the mimA oligonucleotide CTAGGACATTATAACGGTTTTTTAGT (Myb site underlined) cloned upstream of the tk promoter of pBLCAT2 (Luckow and Schutz 1987). For reporter $5 \mathrm{mim} / \mathrm{SV} / \mathrm{CAT}$, the 200-bp SV40 enhancer fragment from $\mathrm{p} \beta 128 \mathrm{SV}$ (Weston 1988) was inserted immediately $5^{\prime}$ of the tk promoter of $5 \mathrm{mim} / \mathrm{CAT}, 3^{\prime}$ of the $5 \mathrm{mim}$ fragment. IE $\beta$ gal (D. Latchman, pers. comm.) contains the HSV-1 IE3 promoter driving a $\beta$-galactosidase gene.

\section{Gel mobility shift assays}

Plasmids pT7 $\beta M T$ and pT7 $\beta M E n T$ were linearized with BamHI and transcribed and translated in vitro by standard methods (Jackson and Hunt 1983; Melton et al. 1984). Proteins were labeled by the incorporation of $\left[{ }^{35} \mathrm{~S}\right] \mathrm{methionine}$ during translation, and their integrity checked by SDS-PAGE and autoradiography. Gel mobility shift assays were performed as described in
Weston (1992), with probe 9M1/9M2, an end-labeled version of the mimA oligonucleotide described above.

\section{Transient expression assays}

Plasmid DNA was introduced into $30-50 \%$ confluent HeLa cells, maintained in Dulbecco's modified Eagle medium (DMEM) and $10 \%$ fetal calf serum, by calcium phosphate coprecipitation (Graham and van der Eb 1973; Busslinger et al. 1981). Transfection mixtures always contained $4 \mu \mathrm{g}$ of IE $\beta g a l$ plasmid (transfection efficiency control) and either $5 \mu \mathrm{g}$ of $5 \mathrm{mim} / \mathrm{CAT}$ or $1 \mu \mathrm{g}$ of $5 \mathrm{mim} / \mathrm{SV} / \mathrm{CAT}$ of reporter plasmid. Effector plasmids pMTV, pSCDMS/MT and pSCDMS/MEnT, or empty pSCDMS vector were added as indicated in the text. The amount of DNA in each transfection was brought up to $20 \mu \mathrm{g}$ by the addition of carrier DNA. Cells were harvested $60 \mathrm{hr}$ posttransfection, and extracts were made by three cycles of freezethawing in $0.25 \mathrm{M}$ Tris $-\mathrm{HCl}(\mathrm{pH} 7.5)$ followed by centrifugation. Equivalent amounts of protein were taken for CAT and $\beta$-galactosidase assays (Miller 1972). Samples were heated to $65^{\circ} \mathrm{C}$ for $10 \mathrm{~min}$ and clarified by centrifugation prior to assay for CAT activity. Acetylated forms of chloramphenicol were separated by thin-layer chromatography, and amounts of acetylated chloramphenicol quantitated using a Molecular Dynamics PhosphorImager. Where necessary, samples whose CAT activity exceeded the linear range of the assay were diluted and reassayed. Data presented are corrected for $\beta$-galactosidase levels and represent the mean and standard deviation of four to seven independent experiments.

\section{RNA and protein analysis}

For RNA analysis from transgenic animals, tissues from 3- to 6-week-old animals were either flash frozen in liquid nitrogen and homogenized in the presence of 1-2 $\mathrm{ml}$ of RNAzol B (Biogenesis Ltd), or disaggregated by pressing through nylon mesh, and treated with RNAzol B. RNA was prepared according to the manufacturer's protocol, and 10-20 $\mu \mathrm{g}$ was loaded onto a $1 \%$ formaldehyde-agarose gel. Following electrophoresis, gels were transferred to Hybond-C extra nitrocellulose (Amersham), and probed by standard methods. The probe used in all experiments was a fragment of pUCMT, containing part of the c-myb DNAbinding domain (nucleotides 251-596; Gonda et al. 1985). The fragment was cloned into M13mp19, and a single-stranded labeled probe generated by primer extension in the presence of $\left[{ }^{32} \mathrm{P}\right] \mathrm{dCTP}$. Blots were stripped and reprobed with a labeled DNA fragment hybridizing to murine GAPDH as a loading control.

Labeled protein extracts were made from disaggregated thymocytes from 3-week-old mice. Cells $\left(5 \times 10^{7}\right)$ were resuspended in $2.5 \mu \mathrm{l}$ of DMEM containing $5 \%$ fetal calf serum, $5 \times 10^{-5} \mathrm{M}$ 2-mercaptoethanol, $25 \mathrm{~mm}$ HEPES (pH 7.4), 1\% glutamine, 1\% sodium pyruvate, and $1 \%$ nonessential amino acids (GIBCO), and lacking methionine and bicarbonate. After addition of 0.75 $\mathrm{mCi}\left[{ }^{35} \mathrm{~S}\right]$ methionine (Amersham), cells were incubated for 2.5 $\mathrm{hr}$, and protein extracts made exactly as described in Coligan et al. (1991). For immunoprecipitations, $200 \mu \mathrm{l}$ of labeled extract, precleared with protein A-Sepharose, was incubated with $50 \mu \mathrm{l}$ of anti-9E10 monoclonal antibody covalently coupled to protein A-Sepharose (kind gift of Gerard Evan; Evan et al. 1985) for $2 \mathrm{hr}$ at $4^{\circ} \mathrm{C}$, in $0.1 \%$ Triton X-100, $0.1 \%$ bovine hemoglobin, $0.01 \mathrm{M}$ Tris $(\mathrm{pH} 8.0), 0.14 \mathrm{M}$ sodium chloride, and $0.025 \%$ sodium azide. Samples were washed as described in Coligan et al. (1991), boiled in $20 \%$ glycerol, $4 \%$ SDS, $0.2 \mathrm{M} \mathrm{DTT}$, and $0.12 \mathrm{M}$ Tris $\mathrm{pH}$ 6.8 ) and loaded onto $12 \%$ SDS polyacrylamide gels. Following electrophoresis for $14 \mathrm{hr}$ at $50 \mathrm{~V}$, gels were fixed in methanol 
and acetic acid, treated with Amplify (Amersham), and dried. Bands corresponding to the MT and MEnT proteins were quantitated by use of a Molecular Dynamics PhosphorImager, and gels were also autoradiographed.

\section{Mice}

For generation of transgenic mice, the MT and MEnT fragments were digested with $\mathrm{BamHI}$ and inserted into the BamHI site of p $\beta G C D 2$ (D. Greenberg and D. Kioussis, unpubl.). This plasmid contains $\sim 0.5 \mathrm{~kb}$ of $5^{\prime}$ sequence from the human $\beta$-globin promoter, a BamHI site for cloning, and a 3-kb noncoding remnant of the $\beta$-globin gene, comprising part of exon 2 , intron 2 , exon 3 , and the $3^{\prime}$-untranslated region up to the polyadenylation site. The $\beta$-globin sequences are followed by the human CD2 LCR (Greaves et al. 1989) contained on a 5.5-kb fragment. p $\beta$ GCD2/ MT was digested with $K p n I$ and NotI, and $\mathrm{p} \beta G C D 2 / M E n T$ with $K p n I$ and SacII, to generate linear fragments either containing promoter and coding sequences fused to the whole $5.5-\mathrm{kb}$ LCR

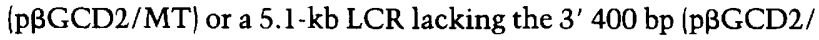
MEnT). DNA fragments were isolated free from vector sequences essentially as described in Lang et al. (1988). Fertilized oocytes from $(\mathrm{CBA} \times \mathrm{C} 57 \mathrm{BL} / 10) \mathrm{F}_{1}$ mice were isolated, and pronuclei injected with the solution of the isolated DNA fragment at a concentration of $1-2 \mu \mathrm{g} / \mathrm{ml}$ in $10 \mathrm{~mm}$ Tris (pH 7.5), $0.2 \mathrm{~mm}$ EDTA. Eggs surviving microinjection were transferred into the oviducts of recipient pseudopregnant females (Hogan et al. 1986).

\section{Flow cytometry}

Single-cell suspensions from thymus and spleen were prepared as described previously (Coligan et al. 1991). Prepared cells $\left(10^{5}\right.$ $\left.10^{6}\right)$ were stained in 96 -well plates for $30 \mathrm{~min}$ at $4^{\circ} \mathrm{C}$ in phosphate buffered saline (PBS) containing $0.1 \%$ sodium azide and $1 \%$ fetal calf serum. Following staining, cells were washed twice and resuspended in $150 \mu \mathrm{l}$ of PBS, $0.1 \%$ sodium azide, and $1 \%$ fetal calf serum. Antibodies were MI93-FITC for CD45,

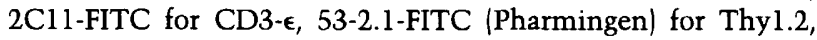
RM2-5-FITC (Pharmingen) for CD2, 58-6.7-FITC (Pharmingen) for $\mathrm{CD} 8 \alpha$, GK1.5-PE (Pharmingen) for CD4, and immunoglobulin-FITC (IgG $, \operatorname{IgG}_{2 a}, \operatorname{IgG}_{2 b}, \operatorname{IgG}_{3}$, IgA, IgM, Fc, and Fab; Nordic Immunological Laboratories Ltd) for immunoglobulin. Dead cells were excluded by staining with propidium iodide. Flow cytometry analysis was carried out on a Becton Dickinson FACScan, and data were analyzed by use of the LYSYS II software.

\section{Lymphocyte proliferation assays}

Lymphoid suspensions were prepared by crushing spleens between layers of nylon mesh in DMEM supplemented with $5 \%$ fetal calf serum, $5 \times 10^{-5}$ M 2 -mercaptoethanol, $1 \%$ glutamine, $1 \%$ sodium pyruvate, $1 \%$ nonessential amino acids (Gibco), and $1 \%$ penicillin/streptomycin. Red and dead cells were removed by centrifugation through Lympho-sep (Seralab). The percentages of $B$ and $T$ lymphocytes in the remaining live cells were determined by flow cytometric analysis with MI93-FITC for CD45, 2C11-FITC for CD3- $\epsilon$, 58-6.7-FITC (Pharmingen) for CD8 $\alpha$, GK1.5-PE (Pharmingen) for CD4, and immunoglobulinFITC $\left(\operatorname{IgG}_{1}, \operatorname{IgG}_{2 a}, \operatorname{IgG}_{2 b}, \operatorname{IgG}_{3}, \operatorname{IgA}, \operatorname{IgM}, \mathrm{Fc}\right.$ and Fab; Nordic Immunological Laboratories Ltd) for immunoglobulin. Cells were plated in triplicate at $5 \times 10^{5}$ cells per well in $96-$ well microtiter plates in DMEM supplemented as above. Triplicate wells received either no stimulant, $2 \mathrm{Cl} 1$ antibody (anti-CD3€) at $0.3 \mu \mathrm{g} / \mathrm{ml}$, or PHA at $0.1 \mu \mathrm{g} / \mathrm{ml}$. Twenty-four hours later, cells were pulsed with $20 \mu \mathrm{l}$ of $\left[{ }^{3} \mathrm{H}\right]$ thymidine at $25 \mu \mathrm{Ci} / \mathrm{ml}$ for
$24 \mathrm{hr}$ and then harvested using a semiautomated sample harvester. Counts per minute per sample were measured in a $\beta$ scintillation counter, and data were computed as the difference in the mean counts per minute of stimulated and unstimulated cultures. The data presented in Figure 6 are derived from 10 (heterozygotes) and 5 (homozygotes) independent experiments.

\section{Acknowledgments}

This work was supported by the Cancer Research Campaign and the Medical Research Council. We thank Jenny Teague for expert technical assistance, Richard Treisman for support, encouragement, and critical reading of the manuscript, and Jim Smith for courier services.

The publication costs of this article were defrayed in part by payment of page charges. This article must therefore be hereby marked "advertisement" in accordance with 18 USC section 1734 solely to indicate this fact.

\section{References}

Anfossi, G., A. Gewirtz, and B. Calabretta. 1989. An oligomer complementary to c-myb-encoded mRNA inhibits proliferation of human myeloid leukemia cells. Proc. Natl. Acad. Sci. 86: 3379-3383.

Biedenkapp, H., U. Borgmeyer, A.E. Sippel, and K.-H. Klempnauer. 1988. Viral myb oncogene encodes a sequence-specific DNA-binding activity. Nature 335: 835-837.

Busslinger, M., N. Moschonas, and R.A. Flavell. 1981. $\beta^{+}$thalassemia: Aberrant splicing results from a single point mutation in an intron. Cell 27: 289-298.

Cantrell, D.A. and K.A. Smith. 1984. The interleukin-2 T-cell system-a new cell-growth model. Science 224: 1312-1316.

Churilla, A.M., T. Braciale, and V. Braciale. 1989. Regulation of T lymphocyte proliferation. J. Exp. Med. 170: 105-121.

Clarke, M.F., J.F. Kukowska-Latallo, E. Westin, M. Smith, and E. Prochownik. 1988. Constitutive expression of a c-myb cDNA blocks Friend murine erythroleukemia cell differentiation. Mol. Cell. Biol. 8: 884-892.

Coligan, J.E., A.M. Kruisbeek, D.H. Margulies, E.M. Shevach, and W. Strober, eds. 1991. Curr. Protocols Immunol. Greene Publishing Associates, New York.

Crabtree, G.R. 1989. Contingent genetic regulatory events in T lymphocyte activation. Science 243: 355-360.

Dubendorff, J.W., L.J. Whittaker, J.T. Eltman, and J.S. Lipsick. 1992. Carboxy-terminal elements of c-Myb negatively regulate transcriptional activation in cis and in trans. Genes \& Dev. 6: 2524-2535.

Duprey, S.P. and D. Boettiger. 1985. Developmental regulation of c-myb in normal myeloid progenitor cells. Proc. Natl. Acad. Sci. 82: 6937-6941.

Egerton, M., R. Scollay, and K. Shortman. 1990. The kinetics of mature T cell development in the thymus. Proc. Nat. Acad. Sci. 87: 2579-2582.

Evan, G.I., G.K. Lewis, G. Ramsay, and J.M. Bishop. 1985. Isolation of monoclonal antibodies specific for the human c-myc proto-oncogene product. Mol. Cell. Biol. 75: 36103616.

Foos, G., S. Grimm, and K.-H. Klempnauer. 1992. Functional antagonism between members of the myb family: B-my $b$ inhibits v-myb-induced gene activation. $E M B O J$. 11: 46194629.

Gewirtz, A.M. and B. Calabretta. 1988. A c-myb antisense oligonucleotide inhibits normal human hematopoiesis in vitro. Science 242: 1303-1306. 
Gewirtz, A., G. Anfossi, D. Venturelli, S. Valpreda, R. Sims, and B. Calabretta. 1989. $G_{1} / S$ transition in normal human T-lymphocytes requires the nuclear protein encoded by c-myb. Science 245: 180-183.

Gill, G. and M. Ptashne. 1988. Negative effect of the transcriptional activator GAL4. Nature 334: 721-724.

Golay, J., A. Capucci, M. Arsura, M. Castellano, V. Rizzo, and M. Introna. 1991. Expression of c-myb and B-myb, but not A-myb, correlates with proliferation in human hematopoietic cells. Blood 77: 149-158.

Gonda, T.J., N.M. Gough, A.R. Dunn, and J. de Blaquiere. 1985. Nucleotide sequence of cDNA clones of the murine myb proto-oncogene. EMBO J. 4: 2003-2008.

Graham, R. and A. van der Eb. 1973. A new technique for the assay of infectivity of human adenovirus DNA. Virology 52: 456-467.

Greaves, D.R., F.D. Wilson, G. Lang, and D. Kioussis. 1989. Human CD2 3 '-flanking sequences confer high-level, $\mathrm{T}$ cell specific, position-independent gene expression in tranenic mice. Cell 56: 979-986.

Han, K. and J.L. Manley. 1993. Functional domains of the Drosophila Engrailed protein. EMBO I. 12: 2723-2733.

Haynes, B.F., S.M. Denning, K.H. Singer, and J. Kurtzburg. 1989. Ontogeny of $T$ cell precursors: A model for the initial stages of human T cell development. Immunol. Today 10: 87-91.

Hogan, B.L.M., F. Constantini, and E. Lacey. 1986. Manipulating the mouse embryo: A laboratory manual. Cold Spring Harbor Press, Cold Spring Harbor, New York.

Howe, K.M. and R.J. Watson. 1991. Nucleotide preferences in sequence-specific recognition of DNA by c-myb protein. $\mathrm{Nu}$ cleic Acids Res. 19: 3913-3919.

Howe, K.M., C.F.L. Reakes, and R.J. Watson. 1990. Characterization of the sequence-specific interation of mouse c-myb protein with DNA. EMBO 1. 9: 161-169.

Jackson, R.J. and R.T. Hunt. 1983. Preparation and use of nuclease treated rabbit reticulocyte lysates for translation of eukaryotic mRNA. Methods Enzymol. 96: 50-74.

Jaynes, J.B. and P.H. O'Farrell. 1991. Active repression by the Engrailed homeodomain protein. EMBO I. 10: 1427-1433.

Lang, G., D. Wotton, M.J. Owen, W.A. Sewell, M.H. Brown, D.Y. Mason, M.J. Crumpton, and D. Kioussis. 1988. The structure of the human CD2 gene and its expression in transgenic mice. EMBO /. 7: 1675-1682.

Liebermann, D.A. and B. Hoffman-Liebermann. 1989. Proto-oncogene expression and dissection of the myeloid growth to differentiation developmental cascade. Oncogene 4: 583592.

Lloyd, A., N. Yancheva, and B. Wasylyk. 1991. Transformation suppressor activity of a Jun transcription factor lacking its activation domain. Nature 352: 635-638.

Luckow, B. and G. Schutz. 1987. CAT constructions with multiple unique restriction sites for the functional analysis of eukaryotic promoters and regulatory elements. Nucleic Acids Res. 715: 5490.

McMahon, J., K.M. Howe, and R.J. Watson. 1988. The induction of Friend erythroleukaemia differentiation is markedly affected by expression of a transfected c-myb cDNA. Oncogene 3: 717-720.

Melton, D.A., P.A. Krieg, M. Rebagliati, T. Maniatis, K. Zinn, and M.R. Green. 1984. Efficient in vitro synthesis of biologically active RNA and RNA hybridization probes from plasmids containing a bacteriophage SP6 promoter. Nucleic Acids Res. 12: 7035-7056.

Miller, J.H. 1972. Experiments in molecular genetics. Cold Spring Harbor Laboratory Press, Cold Spring Harbor, New York.
Mucenski, M.L., K. McLain, A.B. Kier, S.H. Swerdlow, C.M. Schreiner, T.A. Miller, D.W. Pietryga, W.J. Scott Jr, and S.S. Potter. 1991. A functional c-myb gene is required for normal murine fetal hepatic hematopoiesis. Cell 65: 677-689.

Nakagoshi, H., C. Kanei-Ishii, T. Sawazaki, G. Mizuguchi, and S. Ishii. 1992. Transcriptional activation of the c-myc gene by the $c-m y b$ and B-myb gene products. Oncogene 7: 12331240 .

Ness, S.A., A. Marknell, and T. Graf. 1989. The v-myb oncogene product binds to and activates the promyelocyte-specific mim-1 gene. Cell 59: 1115-1125.

Nomura, N., M. Takahashi, M. Matsui, S. Ishii, T. Date, S. Sasamoto, and R. Ishizaki. 1988. Isolation of human cDNA clones of $m y b$-related genes, A-myb and B-myb. Nucleic Acids. Res. 16: 11075-11089.

Palmer, D.B., A. Hayday, and M.J. Owen. 1993. Is TCR $\beta$ expression an essential event in early thymocyte development? Immunol. Today 14: 460-462.

Pollock, R. and R. Treisman. 1990. A sensitive method for determination of protein-DNA binding specificities. Nucleic Acids. Res. 18: 6197-6204.

Poole, S.J., L.M. Kauvar, B. Drees, and T. Kornberg. 1985. The engrailed locus of Drosophila-Structural analysis of an embryonic transcript. Cell 40: $37-43$.

Ramsay, R.G., S. Ishii, and T.J. Gonda. 1991. Increase in specific DNA binding by carboxyl truncation suggests a mechanism for activation of Myb. Oncogene 6: 1875-1879.

Reed, J.C., J. Alpers, P.C. Nowell, and R.G. Hoover. 1986. Sequential expression of protooncogenes during lectin-stimulated mitogenesis of normal human lymphocytes. Proc. Nat. Acad. Sci. 83: 3982-3986.

Rodewald, H.-R., K. Awad, P. Moingeon, L. D'Adamio, D. Rabinowitz, Y. Shinkai, F.W. Alt, and E.L. Reinherz. 1993 Fc $\gamma$ RII/RIII and CD2 expression mark distinct subpopulations of immature CD4-CD8-murine thymocytes: In vivo developmental kinetics and $\mathrm{T}$ cell receptor $\beta$ chain rearrangement status. J. Exp. Med. 177: 1079-1092.

Sakura, H., C. Kanei-Ishii, T. Nagase, H. Nakagoshi, T.J. Gonda, and S. Ishii. 1989. Delineation of three functional domains of the transcriptional activator encoded by the c-myb protooncogene. Proc. Natl. Acad. Sci. 86: 5758-5762.

Sheiness, D. and M. Gardinier. 1984. Expression of a proto-oncogene (proto-myb) in hemopoietic tissues of mice. Mol. Cell. Biol. 4: 1206-1212.

Shortman, K. 1992. Cellular aspects of early T-cell development. Curr. Opin. Immunol. 4: 140-146.

Siu, G., A.L. Wurster, J.S. Lipsick, and S.M. Hedrick. 1992. Expression of the CD4 gene requires a Myb transcription factor. Mol. Cell. Biol. 12: 1592-1604.

Stern, J.B. and K.A. Smith. 1986. Interleukin-2 induction of $\mathrm{T}$-cell $\mathrm{G}_{1}$ progression and $\mathrm{c}-\mathrm{myb}$ progression. Science 233: 203-206.

Thompson, C.B., P.B. Challoner, P.E. Neiman, and M. Groudine. 1986. Expression of the c-myb proto-oncogene during cellular proliferation. Nature 319: 374-380.

Todokoro, K., R.J. Watson, H. Higo, H. Amanuma, S. Kuramochi, H. Yanagisawa, and Y. Ikawa. 1988. Down-regulation of c-myb gene expression is a prerequisite for erythropoietininduced erythroid differentiation. Proc. Natl. Acad. Sci. 85: 8900-8904.

Watson, R.J., C. Robinson, and E.W.-F. Lam. 1993. Transcription regulation by murine $\mathrm{B}-m y b$ is distinct from that by c-myb. Nucleic Acids Res. 21: 267-272.

Weston, K. 1988. An enhancer element in the short unique region of human cytomegalovirus regulates the production of a group of abundant immediate early transcripts. Virology 
Badiani et al.

162: $406-416$.

1990. The myb genes. Sem. Cancer Biol. 1: 371-382.

1992. Extension of the DNA binding consensus of the chicken c-Myb and v-Myb proteins. Nucleic. Acids Res. 20: 3043-3049.

Weston, K. and J.M. Bishop. 1989. Transcriptional activation by the v-myb oncogene and its cellular progenitor, c-myb. Cell 58: 85-93.

Whiteside, S. 1992. "Regulation of human $\beta$ interferon gene expression." Ph.D. thesis, University of London, UK.

Yanagisawa, H., T. Nagasawa, S. Kuramochi, T. Abe, Y. Ikawa, and K. Todokoro. 1991. Constitutive expression of exogenous c-myb gene causes maturation block in monocytemacrophage differentiation. Biochim. Biophys. Acta 1088: 380-384. 


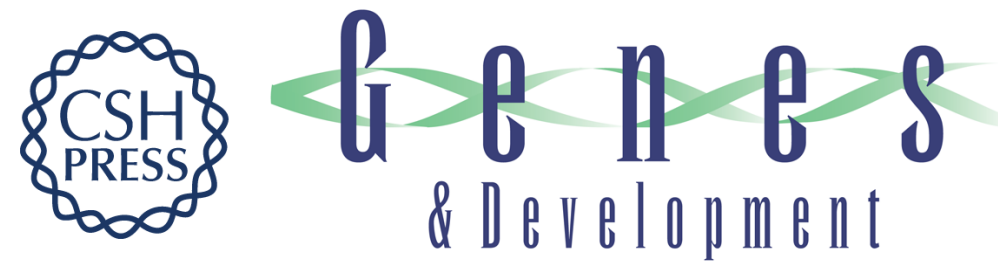

\section{Dominant interfering alleles define a role for c-Myb in T-cell development.}

P Badiani, P Corbella, D Kioussis, et al.

Genes Dev. 1994, 8:

Access the most recent version at doi:10.1101/gad.8.7.770

References This article cites 54 articles, 18 of which can be accessed free at:

http://genesdev.cshlp.org/content/8/7/770.full.html\#ref-list-1

License

Email Alerting

Service

Receive free email alerts when new articles cite this article - sign up in the box at the top right corner of the article or click here.

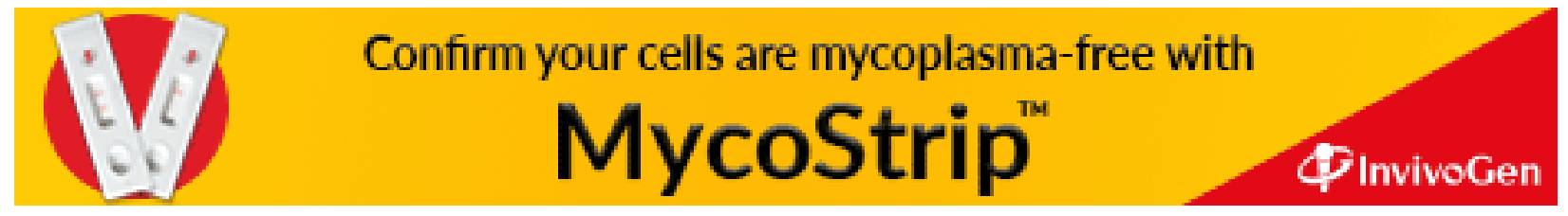

